\title{
Tough on Crime? Pfizer and the CIHR
}

\section{Sévère à l'égard de la criminalité? Pfizer et les IRSC}

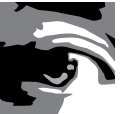

by ROBERT G. EVANS

\begin{abstract}
The appointment of Dr. Bernard Prigent, vice-president and medical director of Pfizer Canada, to the Governing Council of the Canadian Institutes of Health Research, outraged many Canadian health researchers. Pfizer has been a "habitual offender," persistently engaging in illegal and corrupt marketing practices, bribing physicians and suppressing adverse trial results. Since 2002 the company and its subsidiaries have been assessed $\$ 3$ billion in criminal convictions, civil penalties and jury awards. The \$2.3-billion settlement in September 2009 - a month before Dr. Prigent's appointment - set a new record for both criminal fines and total penalties. A link with Pfizer might well advance the commercialization of Canadian research - unhindered by law or morality. Is that now the only mandate, Dr. Beaudet?
\end{abstract}

\section{Résumé}

La nomination du Dr Bernard Prigent, vice-président et directeur médical de Pfizer Canada, au conseil d'administration des Instituts de recherche en santé du Canada a indigné plusieurs chercheurs du milieu de la santé au Canada. Pfizer est un « récidi- 
viste », souvent impliqué dans des pratiques commerciales illégales ou malhonnêtes, offrant des pots-de-vin aux médecins et discréditant les résultats d'essais jugés indésirables. Depuis 2002, le montant total des condamnations, des amendes administratives et des amendes prononcées par des jurys, imposées à la firme et à ses filiales, est évalué à 3 milliards de dollars. L'amende de 2,3 milliards de dollars, prononcée en septembre 2009, a établi un record tant pour les amendes au criminel que pour l'ensemble des sanctions pénales. Les liens avec Pfizer peuvent sans doute faire progresser la commercialisation de la recherche au Canada - sans les entraves de la loi ou de la morale. Est-ce donc là votre unique mandat, Docteur Beaudet?

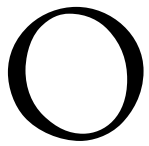

N JANuARy I5 OF This year, US federal prosecutors in Boston filed a complaint against Johnson \& Johnson (J\&J) and related companies, alleging violations of the federal False Claims Act and related legislation (Associated Press 2010). ${ }^{1}$ Allegedly, from 1999 through 2004, J\&J made payments to Omnicare to induce increased prescribing of Risperdal to patients in nursing homes. Risperdal is J\&J's brand of risperidone, a drug used in the treatment of schizophrenia.

The inducement was somewhat indirect. Omnicare is a pharmaceutical services provider, the largest in North America, that contracts with nursing homes and other facilities to provide drugs prescribed by patients' physicians. Omnicare's pharmacists dispense these drugs; they also provide oversight of patients' drug use and health condition. According to the complaint, Omnicare pharmacists review patients' charts at least monthly and make prescribing recommendations that physicians follow more than $80 \%$ of the time.

The ultimate objective of all prescription drug marketing is to determine what is written on the prescription pad. In this case, the chain of influence ran from drug company to dispensing contractor to pharmacist to physician. Over the period alleged, J\&J sales through Omnicare rose from $\$ 100$ million to $\$ 280$ million. Risperdal made up more than one-third of these sales.

Omnicare's website stresses the company's mission to promote the health of seniors.

\section{Omnicare: The Prescription for Positive Outcomes}

Omnicare is the nation's leading provider of pharmaceutical care for seniors. Each day, our pharmacists serve more than 1.4 million residents of skilled nursing, assisted living, and other healthcare facilities in 47 states and Canada. While doing this, we capture a tremendous amount of data. Omnicare combines this data with its proprietary outcomes algorithm technology, based on best practices in geriatric medicine, to identify and help treat diseases in the elderly. 
We do all this, and much more, with one goal in mind: to help ensure the health of seniors in a cost-effective manner. (Omnicare 2010)

This noble language might suggest that Omnicare is "an eleemosynary outfit." Not so. It is a strictly for-profit corporation (OCR-N on the NYSE) like Johnson \& Johnson $(J N J-N)$, with the mission - the one for which its executives are paid - of providing "enhanced shareholder value" - i.e., profit for its shareholders. For the hardeyed men and women of Wall Street, the rest is just public relations fluff. Payments from J\&J to Omnicare to encourage pharmacists to promote the prescribing of Risperdal were a win-win strategy for both corporations.

For patients, perhaps not so much. Atypical antipsychotic drugs such as risperidone can have some quite nasty side effects; in particular, the US Food and Drug Administration requires manufacturers to include special labelling warning of an increased risk of death related to psychosis and behavioural problems in elderly patients with dementia.

Kickbacks in the nursing home pharmacy context are particularly nefarious because they can result in excessive prescribing of strong drugs to patients who have little or no control over the medical care they are receiving. ... Nursing home doctors should be able to rely on the integrity of the recommendations they receive from pharmacists, and those recommendations should not be a product of money that a drug company is paying to the pharmacy. (US Attorney Carmen Ortiz, quoted in Associated Press 2010).

In addition to the risks to patients, the other side of the coin of corporate gain was the cost to public and private payers. But these interests, like those of patients, were not represented when J\&J implemented a strategy of, in effect, purchasing Omnicarés nursing home pharmacists to act as an extension of its own sales force.

The charges against J\&J have not been proven in court, nor are they likely to be. Corporations prefer not to go to trial; rather, they negotiate a settlement that will permit them to continue denying wrong-doing while paying to make the charges go away. (Such settlements may, however, include a formal guilty plea on one or more criminal charges.) Omnicare, as it happens, settled related charges last November for a payment of $\$ 98$ million to the United States and state governments (Associated Press 2010); with that case settled, J\&J will probably choose the same option. The only real issue in dispute will be the size of the penalties.

The amount of money involved in this case is in fact very small potatoes. J\&J will probably pay a couple of hundred million in fines and civil penalties. The stakes were somewhat higher last September, when Pfizer and related companies settled a number of charges for a total of $\$ 2.3$ billion (O'Reilly and Capaccio 2009). This settlement 
set a new record for a criminal fine - $\$ 1.2$ billion - plus civil penalties of $\$ 1$ billion. Subsidiary Pharmacia \& Upjohn pleaded guilty to one count of a felony, misbranding of a pharmaceutical, and was assessed a forfeiture of $\$ 100$ million.

A number of fraudulent marketing practices were involved for a number of different Pfizer or subsidiary products. The criminal charges focused on the illegal promotion of several Pfizer brands - Bextra (valdecoxib, a pain medication, since removed from the market), Geodon (ziprasidone $\mathrm{HCl}$, an atypical antipsychotic), Zyvox (linezolid, an antibiotic) and Lyrica (pregabalin, a seizure medication). These were promoted for "off-label" use, i.e., for uses other than those approved by the FDA. ${ }^{3}$ But there were also kickbacks to physicians and the use of unverified and misleading marketing materials to promote the prescribing of several other Pfizer brands, including Viagra (sildenafil) and Lipitor (atorvastatin).

This was by no means Pfizer's first offence. In 2007, Pfizer subsidiary Pharmacia \& Upjohn paid \$34 million and pleaded guilty to paying kickbacks for formulary placement of its drugs and entered into a Deferred Prosecution Agreement for offlabel distribution of Genotropin, its brand for the human growth hormone somatropin (US Department of Health \& Human Services and US Department of Justice n.d.).

In 2004, Pfizer subsidiary Warner-Lambert pleaded guilty and paid more than $\$ 430$ million to resolve criminal charges and civil liability arising from its fraudulent marketing practices with respect to Neurontin, its brand for the drug gabapentin. Originally developed for the treatment of epilepsy, Neurontin was illegally promoted off-label for the treatment of various forms of neurological pain, and in particular for migraine.

In 2002, Pfizer and its subsidiaries Warner-Lambert and Parke-Davis paid $\$ 49$ million to resolve civil claims that it had failed to report best prices for its drug Lipitor as is required under the Medicaid Drug Rebate Statute.

As this is being written, gabapentin is back in the news. The CBC (2010) reports that

Pfizer has been ordered to pay $\$ 142$ million US in damages for fraudulently marketing gabapentin, an anti-seizure drug marketed under the name Neurontin. A federal jury in Boston ruled Thursday that Pfizer fraudulently marketed the drug and promoted it for unapproved uses. ${ }^{4}$

This case demonstrates one reason why drug companies often prefer to settle rather than go to trial. The $\mathrm{CBC}$ report continues:

Data revealed in a string of U.S. lawsuits indicates the drug was promoted by the drug company as a treatment for pain, migraines and bipolar disorder even though it wasn't effective in treating these conditions and was actually 
toxic in certain cases, according to the Therapeutics Initiative, an independent drug research group at the University of British Columbia.

The trials forced the company to release all of its studies on the drug, including the ones it kept hidden.

A new analysis of those unpublished trials by the Therapeutics Initiative suggests that gabapentin works for one out of every six or eight people who use it, at best. The review also concluded that one in eight people had an adverse reaction to the drug.

Dr. Tom Perry, quoted in the story, estimates that Neurontin sales in Canada are around $\$ 300$ million per year. Since the drug has been in use since the late 1990s, at least a billion dollars has been spent on an illegally promoted drug with few benefits and serious side effects.

In response to this record of persistent criminal behaviour, the September 2009 settlement included Pfizer's signing of an "integrity agreement" to be overseen by the US Department of Health \& Human Services. In essence, while denying virtually all charges of wrong-doing, Pfizer accepted a form of trusteeship for a period of years, to try to prevent the company from doing in the future what it denied having done in the past. ${ }^{5}$

The integrity agreement, however, imposed the further requirement that Pfizer make public its cash payments to practitioners. On March 31, 2010, the New York Times reported that

Pfizer ... paid about $\$ 20$ million to 4,500 doctors and other medical professionals in the United States for consulting and speaking on its behalf in the last six months of $2009 \ldots$... [and] $\$ 15.3$ million to 250 academic medical centers and other research groups for clinical trials .... (Wilson 2010)

While most of the disclosures were required by the integrity agreement, "[c]ompany executives said they had long planned to be more transparent." The "skepticism [of] some outside experts" may have been reinforced by the fact that Pfizer's website (like those of Eli Lilly, Merck and GlaxoSmithKline) is "set up in ways that make it difficult to download and analyze the entire database" (Wilson 2010). It is also notable that the integrity agreement does not apply to payments made to physicians outside the United States - in Canada, for example - and accordingly, none of these were disclosed.

An integrity agreement was also imposed in the previous record settlement of health industry fraud charges, the $\$ 1.7$ billion paid by the Hospital Corporation of America (HCA) in 2003 (US Department of Justice 2003b). In this case, the charges involved "false claims arising from a variety of allegedly unlawful practices, including 
cost report fraud and the payment of kickbacks to physicians" (US Department of Justice 2003a) as well as fraudulent billings of various types. But in the HCA case the Department of Justice also proceeded against a number of corporate executives. A corporation may treat both criminal and civil penalties as simply business expenses, to be weighed against the revenues earned from illegal behaviour. But human beings can be put in jail, and that is a whole other matter. Conceivably, convicting corporate executives of criminal behaviour and sentencing them to terms of imprisonment might be a more effective deterrent to the "repeat offender" behaviour demonstrated by Pfizer.

Unfortunately, while several HCA executives were indicted, the American courts threw out the charges against individuals. The corporation - i.e., its shareholders incurred the financial penalties; the executives involved were presumed innocent. In the absence of such personal liability, both criminal and civil penalties appear to be, to Pfizer at least, a business expense worth incurring. You have to spend money to make money.

This point was illustrated in 1998, when the Canadian courts rejected a suit by Bristol-Myers Squibb to suppress a research report on the effectiveness of various forms of statins. CCOHTA (the Canadian Coordinating Office of Health Technology Assessment, now the Canadian Agency for Drugs and Technologies in Health) had found that statins were, indeed, effective in lowering blood levels of LDLs, but that no one variant had an advantage over others on the market. BristolMyers Squibb's pravastatin (branded as Pravachol) had the leading market share in Canada, and the company feared that this assessment might undercut its marketing. The company sought an injunction forbidding the report's release. This was denied. The company appealed the ruling. The appeal was denied.

But Bristol-Myers Squibb won by losing. The release of the report was delayed from December 1997 until May 1998, and a large part of CCOHTA's budget, and the time and focus of its staff, were diverted to litigation. As the Journal of the American Medical Association reported," $[t]$ he $\$ 230,000$ that CCOHTA spent on lawyers to defend the right to publish its report represents approximately the income from a single day of sales of Pravachol in Canada, but it amounts to 13\% of CCOHTA's annual budget" ("Drug Firm Suit Fails to Halt Publication of Canadian Health Technology Report" 1998). The costs of (probably predictably) unsuccessful litigation were well worth incurring as was the opprobrium of the research community. Memories are short. ${ }^{6}$

Nor are the financial penalties very significant compared to the size of the companies involved (see Table 1).

In eight years of repeated malfeasance, Pfizer has accumulated just under $\$ 3$ billion in fines and civil penalties, or only about a third of last year's net revenues. For $\mathrm{J} \& \mathrm{~J}$, a penalty of $\$ 200-\$ 300$ million would hardly count as pocket change.

But the world evolves. In January 2010 the FBI, operating in conjunction with authorities in the United Kingdom and Israel, executed a "sting" operation against a number of mostly small-time arms dealers who offered bribes to the "representatives" 
of a fictitious African nation to secure equally fictitious contracts to supply arms and ammunition. This is an offence under the US Foreign Corrupt Practices Act (FCPA), and the charges are laid against the individuals who offer bribes or otherwise engage in corrupt practices as defined by American law. The FBI were careful to ensure that the victims of the sting were fully aware that their intended actions were illegal. Twentytwo executives were then arrested, all but one in Las Vegas (where else?).

TABLE 1. Sales and net revenues, based on 2009 annual reports of the world's 12 largest pharmaceutical firms (millions USD)

\begin{tabular}{|l|c|c|}
\hline Company & Revenue & Net Income \\
\hline Johnson \& Johnson & 61,897 & 12,266 \\
Pfizer & 50,009 & 8,635 \\
Roche & 45,304 & 7,860 \\
GlaxoSmithKline & 44,421 & 8,877 \\
Novartis & 44,267 & 8,454 \\
Sanofi-Aventis & 40,870 & 11,814 \\
AstraZeneca & 32,804 & 7,544 \\
Abbott Laboratories & 30,800 & $\mathrm{~N} / \mathrm{A}$ \\
Merck & 27,428 & 13,024 \\
Bristol-Myers Squibb & TBA & TBA \\
Bayer Healthcare & 22,297 & 2,365 \\
Eli Lilly & 21,836 & 4,328 \\
\hline
\end{tabular}

Source: http://en.wikipedia.org/wiki/List_of_pharmaceutical_companies. Retrieved April 9, 2010.

This operation was the first under a new modus operandi for the US Department of Justice, involving a "campaign-style" approach targeting industries identified as highly corrupt and then trying to bring simultaneous prosecutions against a large number of people in those industries. It also featured close transatlantic cooperation between the FBI and the City of London police (Henriques 2010).

What is of particular interest is that the next industry to be targeted using the Foreign Corrupt Practices Act was pharmaceuticals. On November 12, 2009, at the 10th Annual Pharmaceutical Regulatory and Compliance Congress and Best Practices Forum, Assistant Attorney General Larry Breuer (chief of the Department of Justice criminal division) cautioned that the level of government involvement in health systems outside the United States makes the environment ripe for bribery, corruption and FCPA violations. He indicated that the department's increased scrutiny of the pharmaceutical industry "will mean investigation and, if warranted, prosecution of corporations ... but also it will involve investigation and prosecution of senior executives" (Main Justice 2009). Will the international nature of the pharmaceutical industry enable such investigations to reach corrupt practices - and individuals - within the United States itself? (Could it reach into Canada?) Answers are probably some years away.

A commercial corporation, as a legal person, differs from natural persons - you 
and me - in being wholly amoral. It is a social organization brilliantly designed for a single purpose - the pursuit of profit. The test of a corporate action is, will it tend to increase profits - or, more generally, the net worth of the corporation? The action may involve the breaking of laws, or threats to the health and well-being of patients or other natural persons. Looking at Pfizer's record, one thinks of the phrase "habitual criminal." But the corporation lacks the mens rea, the guilty mind, associated with criminality in the natural person. Amoral, purely legal persons recognize no moral restraints, so are no more capable of feeling guilt than a robot (Bakan 2004).

But "Corporations don't lie, steal, conceal, plunder, bribe and scheme. People do."7 The corporate form typically permits corporate executives to escape personal accountability. The key to discouraging corporate malfeasance in the pharmaceutical industry may therefore lie in reaching through the corporate veil to charge those natural persons whose decisions determine the behaviour of the corporation.

But there is no risk of that happening in Canada. In sharp contrast to the US Department of Justice, regulatory authorities in Canada are reminiscent of Monty Python's parrot. ${ }^{8}$ To the contrary, and to the outrage of much of Canada's health research community, the vice-president and medical director of Pfizer Canada, Dr. Bernard Prigent, was on October 5, 2009, appointed to the Governing Council of the Canadian Institutes of Health Research (CIHR), the premier national institution for funding health research.

This extraordinary appointment raises very troubling questions about the motivations not only of the Canadian federal government, but also of Dr. Alain Beaudet, the president of CIHR. Dr. Beaudet is well aware (unlike, one suspects, most of Mr. Harper's Conservatives) of the difference between genuine pharmaceutical innovation and a marketing masquerade. Yet the appointment can only have been made on his recommendation, or at least with his blessing. What was he thinking when he decided to get into bed with Pfizer, and deliberately snubbed so many Canadian health researchers? Is it conceivable that Dr. Beaudet was simply unaware of Pfizer's record of persistent criminal behaviour and casual disregard for the health and well-being of patients? That would be a major failure of due diligence; the record is all in the public domain and readily available. Was he bowing to government pressure? Again, unlikely. People of integrity, under political pressure to betray the public trust, should and do resign.

The most plausible explanation may be that Dr. Beaudet shares the federal government's objective of promoting the increased commercialization of research in Canada - at whatever cost. He may see a closer relationship with Pfizer as a way to increase funding for drug research - perhaps even for the CIHR - and of currying favour with Ottawa. But while Dr. Beaudet undoubtedly recognizes a distinction between "commercialization" and drug pushing, Pfizer does not. Does Dr. Beaudet consider the company's history of criminal settlements, guilty pleas and convictions irrelevant to this appointment - or even a positive recommendation? If all that matters is increased 
sales of drugs, regardless of their benefits, Pfizer is the one to call. ${ }^{9}$ Dr. Beaudet's CIHR, like Mr. Harper's federal government, may just hope to share the loot. ${ }^{10}$

A closer relationship with Pfizer, and the drug industry generally, may indeed promote greater commercialization of Canadian research. If so, Pfizer and other shareholders will reap the benefits, as will those Canadian researchers who become their "out-house" (as opposed to in-house) research departments. Dr. Beaudet's political masters, apparently believing that an expanded drug industry is an end in itself regardless of the consequences for the health of Canadians or the costs of healthcare, will also be pleased. All economic activity - beneficial, harmful or just plain ineffectual - is included in the gross domestic product. Illegal and corrupt marketing practices, and the drugs they promote, all contribute to "economic growth" as well as drug company profit.

But Pfizer's track record inspires no confidence whatever that the health of Canadians will benefit in proportion, if at all, from any such growth. What is certain is that any benefits in health or wealth from this relationship will be paid for, and over-paid, by Canadian patients, insurers and taxpayers. Dr. Beaudet has allowed the commercialization mandate to override CIHR's responsibilities to Canadians. Pfizer is not an eleemosynary outfit.

\section{Acknowledgements}

With thanks to Morris Barer and Steven Lewis.

\section{NOTES}

1. See also US Department of Justice, "United States Files Suit against Drug Manufacturer Johnson \& Johnson." Retrieved April 9, 2010. <http://www.justice.gov/usao/ma/Press\%20 Office\%20-\%20Press\%20Release\%20Files/Jan2010/JohnsonandJohnsonPR.html> .

2. "Around the headquarters in Rahway, New Jersey, there is so much high-minded talk about Merck's life saving mission that one might consider the company an eleemosynary outfit. But this mis-impression is never conveyed in conversation with [the president] who is as devout a disciple of the bottom line as ever there was." (Robertson 1976: 136)

3. Physicians may prescribe a drug for an off-label use, but the manufacturer may not legally promote it for such use.

4. The suit was brought by Kaiser Foundation Health Plan Inc. and Kaiser Foundation Hospitals, and was described in Business Week as a "civil racketeering trial." See www.businessweek.com/ news/2010-03-23/pfizer-defends-epilepsy-drug-neurontin-at-fraud-trial-in-boston.html.

5. Having done no wrong, Pfizer presumably paid $\$ 2.3$ billion just to avoid the trouble of proving its innocence in court.

6. Coincidentally, the offices of CCOHTA in Ottawa were burgled during this dispute, and computer disks were stolen, but no suspects were ever identified.

7. Steven Lewis, obviously inspired by the National Rifle Association of the United States. 
8. Perhaps if the federal government rather than the provinces had to pay for pharmaceuticals, they might be more energetic. But white-collar crime seems to be taken much less seriously in Canada. Recall that Conrad Black was tried, convicted and imprisoned in the United States for "obstruction of justice," removal of documents in blatant violation of a court order. The order was issued and the offence occurred in Canada; no charges were laid here.

9. Pfizer is no different from any other pharmaceutical firm, only larger and more egregious.

10. If that is the only objective, why not legalize (and tax) B.C. Bud? Because that would upset the Americans, who are armed and dangerous.

\section{REFERENCES}

Associated Press. 2010 (January 15). "J\&J Alleged to Have Paid Kickbacks." The Globe and Mail. Retrieved April 9, 2010. <http://v1.theglobeandmail.com/servlet/story/RTGAM.20100115.escenic_1432378/BNStory/Business/>.

Bakan, J. 2004. The Corporation: The Pathological Pursuit of Profit and Power. Toronto: Penguin Canada.

CBC News. 2010 (March 26). “Pfizer to Pay \$142M for Drug Fraud.” Retrieved April 9, 2010. <http://www.cbc.ca/health/story/2010/03/25/gabapentin-ubc.html?ref=rss>.

"Drug Firm Suit Fails to Halt Publication of Canadian Health Technology Report." 1998 (August 26). Journal of the American Medical Association 280(8): 683-84.

Henriques, D.B. 2010 (January 20). "FBI Charges Arms Sellers with Foreign Bribes." The New York Times. Retrieved April 9, 2010. <http://www.nytimes.com/2010/01/21/business/21sting. html>.

Main Justice. 2009 (November 12). “Criminal Division Chief Breuer's FCPA Pharma Speech." Retrieved April 9, 2010. <http://mainjustice.virtual.vps-host.net/2009/11/12/criminal-divisionchief-breuers-fcpa-pharma-speech/ $>$.

Omnicare Inc. 2010. Retrieved April 9, 2010. <http://www.omnicare.com/home.asp>.

O’Reilly, C. and T. Capaccio. 2009 (September 2). "Pfizer Agrees to Record Criminal

Fine in Fraud Probe." Retrieved April 9, 2010. <http://www.bloomberg.com/apps/ news?pid=20601103\&sid=a4h7V5lc_xXM>.

Robertson, W. 1976 (March). "Merck Strains to Keep the Pots Aboiling." Fortune, pp. 134-39, 168,170 .

US Department of Health \& Human Services and US Department of Justice n.d."Pfizer Fact Sheet." STOP Medicare Fraud. Retrieved April 9, 2010. <http://www.stopmedicarefraud.gov/pfizerfactsheet.html>.

US Department of Justice. 2003a (June 26). "Largest Health Care Fraud Case in US History Settled." Retrieved April 9, 2010. <http://www.justice.gov/opa/pr/2003/June/03_civ_386.htm>. US Department of Justice. 2003b (November 10). "Justice Dept. Civil Fraud Recoveries Total \$2.1 Billion for FY 2003.” Retrieved April 9, 2010. <http://www.justice.gov/opa/pr/2003/ November/03_civ_613.htm >.

Wilson, D. 2010 (March 31). "Pfizer Details Payments to Doctors and Researchers." The New York Times. Retrieved April 9, 2010. <http://www.nytimes.com/2010/04/01/ business $/ 01$ payments.html?ref=health $>$. 